\title{
Az integrált viselkedéses modell alkalmazása az egészségmagatartás befolyásolására II.
}

\author{
Kiss Marietta - Fehér András - Kontor Enikő \\ Debreceni Egyetem
}

\begin{abstract}
A TANULMÁNY CÉLJA
Számos elmélet található a hazai és nemzetközi szakirodalomban, melyek az egészségmagatartás különbözö formáit igyekeznek magyarázni. Ezek egyik körét jelentik a társas-kognitív magatartási elméletek, melyek sikeresen jeleztek előre és magyaráztak számos magatartást, köztük sokféle egészségmagatartás-formát, illetve számos eredményes, viselkedésváltozást célzó beavatkozás alapjául is szolgáltak. A több társas-kognitív magatartási modell integrálásával létrejött integrált viselkedéses modell hasonlóan sikeresnek bizonyult bizonyos egészségmagatartás-formák magyarázatában, előrejelzésében és a viselkedésváltozást célzó programok megalapozásában is, mégsem terjedt el széles körben a használata, különösen a hazai szakirodalomban. Kétrészes tanulmányunk célja ezért elméleti áttekintést adni a modell felépítéséről és használatának módjáról, ezzel segítve a jövőbeli alkalmazását a hazai empirikus kutatásokban az egészségmagatartás (és esetleg más magatartásformák) területén.
\end{abstract}

\section{ALKALMAZOTT MÓDSZERTAN}

Tanulmányainkban szekunder kutatás segítségével tártuk fel és mutattuk be az integrált viselkedéses modell eredetével, felépítésével, valamint gyakorlati alkalmazásával kapcsolatos hazai, illetve nemzetközi szakirodalmat.

\section{LEGFONTOSABB EREDMÉNYEK}

Jelen tanulmány az integrált viselkedéses modell gyakorlati alkalmazásának kérdéseit mutatja be, míg az első rész a modell elméleti alapjait és felépítését taglalta. Mivel a magyar szakirodalomból a modell szinte teljesen hiányzik, a kapcsolódó elméleti és gyakorlati tapasztalatok szisztematikus áttekintése hiánypótlónak tekinthető.

\section{GYAKORLATI JAVASLATOK}

Az integrált viselkedéses modell a szakirodalomban fellelhető és a tanulmányban bemutatott módszertan alapján, a korábbi példák analógiájára sikerrel alkalmazható olyan egészségmagatartás-formák esetén, melyeket eddig a szakirodalom más elméletekkel próbált magyarázni.

Kulcsszavak: integrált viselkedéses modell, szándékolt cselekvés elmélete, tervezett cselekvés elmélete, egészségmagatartás

Köszönetnyilvánitás: A publikáció elkészítését az EFOP-3.6.2-16-2017-00003 számú projekt támogatta. A projekt az Európai Unió támogatásával, az Európai Szociális Alap társfinanszírozásával valósult meg.

DOI: 10.15170/MM.2020.54.KSZ.II.06 


\section{AZ INTEGRÁLT VISELKEDÉSES MODELL ALKALMAZÁSÁNAK MÓDSZERTANA

METHODOLOGY OF USE OF
THE INTEGRATED
BEHAVIORAL MODEL

Kasprzyk et al. (1998), Kasprzyk és Montaño (2007) és különösen Montaño és Kasprzyk (2008) részletesen leírja az integrált viselkedéses modell (IBM) alkalmazásának módszertanát. Ahogy több tanulmány (Fishbein et al. 2002, Fishbein \& Cappella 2006, Fishbein \& Yzer 2003) megjegyzi, elöször fontos a vizsgálandó magatartás világos meghatározása, ugyanis a beavatkozások akkor lesznek hatékonyak, ha egy specifikus magatartást céloznak (például háromszor egy héten 20 percet sétálni), nem pedig egy magatartáskategóriát (testmozgás) vagy célt (például fogyás). Ezért a megcélzandó viselkedést a cselekvés, a cél, a kontextus és az időtáv függvényében kell meghatározni (Danter 2005, Fishbein 2000, Fishbein et al. 2002, Fishbein \& Cappella 2006, Moñtano \& Kasprzyk 2008). Moñtano és Kasprzyk (2008) kutatása - melyben a válaszadók szándékát vizsgálták arra vonatkozóan, hogy az elkövetkezö három hónapban állandó partnerükkel mindig használnak óvszert - jó példát szolgáltat erre, itt világos a cselekvés (használat), a cél (óvszer), a kontextus (állandó partnerrel mindig) és az időtáv (a következő három hónapban). A négy tényező bármelyikének megváltoztatása megváltoztatja a kérdéses viselkedést (Fishbein 2000, Fishbein et al. 2001, Fishbein \& Cappella 2006).
Az empirikus kutatás első lépése a kvalitatív kutatás, azaz fókuszcsoportos interjúk (Kasprzyk \& Montaño 2007) vagy nyitott személyes mélyinterjúk (Montaño \& Kasprzyk 2008) lefolytatása az érintettekkel, melynek során az adott magatartással kapcsolatos ismeretekröl, véleményekről, a magatartás okairól, a modell konstrukcióival kapcsolatos információkról, érzésekről, hiedelmekről, a normatív befolyás forrásairól, illetve a magatartást akadályozó és az azt elősegítő tényezőkről kérdezik a résztvevőket (1. táblázat). Javasolt, hogy az interjúk résztvevőinek fele olyan személy legyen, aki már követi az adott magatartást vagy szándékozik azt követni, míg a résztvevők másik fele olyan legyen, akik még nem követik azt. Az interjúkat a „telítettség” eléréséig érdemes folytatni, azaz addig, amikor már új információ nem merül fel. Az interjúk kvalitatív tartalomelemzése szolgál a modellkonstrukciókat mérni szándékozó kérdőív alapjául: először a modell egyes elemeit jellemzö listákat állítanak össze, majd ezek alapján fogalmazzák meg a konkrét kérdéseket. A kvalitatív kutatási fázis jelentősége abban áll, hogy segítségével lehet az IBM modellkonstrukcióit empirikusan megerősíteni, illetve csak e fázis eredményeire építve lehet a célsokaság kulturális és egyéb jellemzőihez illeszkedö kérdőívet összeállítani. A tartalomelemzés eredményeként létrejött kérdőívet érdemes pilot tesztnek alávetni, amely segít a kérdéseket világossá, a skálákat pedig megbízhatóvá tenni és az adott kultúrához igazítani, illetve a redundáns, kis varianciájú kérdéseket kizárni. Braun (2012) a pilot teszt elött a kérdőív látszat- vagy felszíni érvényességét (face validity) és tartalmi érvényességét (content validity) a téma öt szakértöjével is ellenőriztette.

\section{1. táblázat: Az interjúk lehetséges kérdései \\ Table 1. Possible questions of interviews}

\begin{tabular}{|l|l|}
\hline Konstrukció & Kérdések \\
\hline Tapasztalati attitűd & $\begin{array}{l}\text { Milyen érzései vannak az X magatartással kapcsolatban? Mit szeret/nem } \\
\text { szeret az X magatartásban? Mit élvez/utál az X magatartásban? }\end{array}$ \\
\hline Instrumentális attitűd & $\begin{array}{l}\text { Mik a pozitívumai az X magatartás folytatásának? (Mik az elönyei az X } \\
\text { magatartás folytatásának? Milyen hasznok származhatnak az X magatartás } \\
\text { folytatásából?) } \\
\text { Mik a negatívumai az X magatartás folytatásának? (Mik a hátrányai az } \\
\text { X magatartás folytatásának? Milyen negatív hatások származhatnak az X } \\
\text { magatartás folytatásából?) }\end{array}$ \\
\hline Normatív befolyás & $\begin{array}{l}\text { Ki támogatná az X magatartás folytatásában? } \\
\text { Ki lenne az ellen, hogy az X magatartást folytassa? }\end{array}$ \\
\hline Észlelt magatartásirányítás & $\begin{array}{l}\text { Mik könnyítik meg, hogy az X magatartást folytassa? } \\
\text { Mik nehezítik meg, hogy az X magatartást folytassa? }\end{array}$ \\
\hline Énhatékonyság & $\begin{array}{l}\text { Ha szeretné folytatni az X magatartást, mennyire biztos abban, hogy meg } \\
\text { tudja azt tenni? } \\
\text { Mik segítenék abban, hogy leküzdje az X magatartás követése előtt álló } \\
\text { akadályokat? }\end{array}$ \\
\hline
\end{tabular}

Forrás: Montaño \& Kasprzyk (2008) 
A következö, kvantitatív (kérdöíves) fázisban a modellkonstrukciók mérése történik, amelyben a különböző kutatások némileg eltérnek. A 2. táblázat jól szemlélteti ezeket az eltéréseket, illetve a hasonlóságokat is.

Hasonlóan a szándékos cselekvés elméletéhez (TRA) és a tervezett cselekvés elméletéhez (TPB), a viselkedéses szándék mögöttes befolyásolói a legtöbb kutatásban az IBM-ben is súlyozott átlagként állnak elö ${ }^{1}$, a következőképpen: az attitüd indirekt mérése a magatartási hiedelmeknek (behavioral beliefs - B) a viselkedés kimenetének értékelésével (outcome evaluation - E), a szubjektív norma indirekt mérése a normatív hiedelmeknek (normative beliefs $-\mathrm{Nb}$ ) a referenciaszemélyeknek való megfelelés motivációjával (motivation to comply - Mc), végül az észlelt magatartásirányítás indirekt mérése a kontrollhiedelmeknek (control beliefs $-\mathrm{Cb}$ ) az észlelt hatással (perceived power - Pp) súlyozott értékével történik, azaz a következöképpen: $\Sigma[\mathrm{BE}] / \mathrm{n}, \Sigma[\mathrm{NbMc}] / \mathrm{n}$, $\Sigma[\mathrm{CbPp}] / \mathrm{n}$ (Kasprzyk \& Montaño 2007, Kenski et al. 2001, von Haeften et al. 2001, von Haeften \& Kenski 2001).

Ahogy azt cikksorozatunk első részében említettük, a legrészletesebben kidolgozott IBM-et Montaño és Kasprzyk (2008) tanulmánya tartalmazza. E modell esetén mind a konstrukciók, mind azok mérése némileg eltér a többi kutatástól, ezért ezek külön táblázatban (3. táblázat) szerepelnek, illetve a következökben részletesen bemutatásra kerülnek ${ }^{2}$.

\footnotetext{
Ez alól kivételt képez Kasprzyk et al. (1998) kutatása, ahol a magatartási hiedelmek és a kimenetek értékelései, valamint a kontrollhiedelmek és az észlelt erősség/hatás egyszerú szorzatként és nem súlyozott átlagként kerülnek be a modellbe. Ez a különbség azonban a modell lényegét nem érinti, mivel a kettő egymásnak csupán skalárszorosa.

2 Montaño és Kasprzyk (2008) szerint az IBM TRA/TPB konstrukcióinak mérésére mind az 5, mind a 7 pontos skálákat lehet használni. A szerzőpáros az általános módszertan ismertetésénél, a bemutatott empirikus kutatás során 5 pontos skálákat használt.
} 


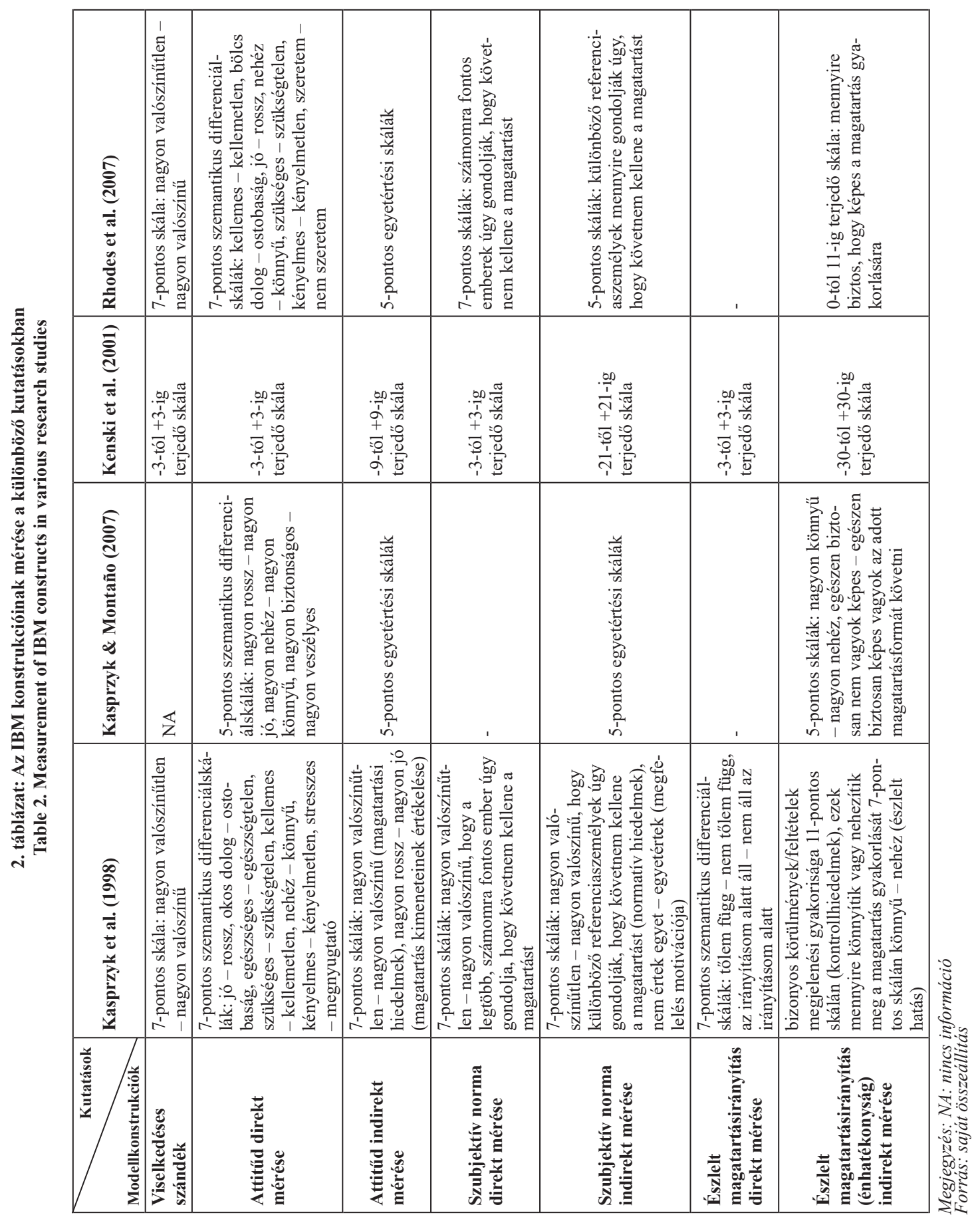

68 MARKETING \& MENEDZSMENT 2020. KÜLÖNSZÁM 2.

TÁPLÁLKOZÁS, EGÉSZSÉG, VÁSÁRLÁSOK 
3. táblázat: A TRA, a TPB és az IBM konstrukciói, azok definíciója és mérése Table 3. Constructs of TRA, TPB and IBM, their definitions and measurement

\begin{tabular}{|c|c|c|c|}
\hline & Konstrukció & Definíció & Mérés \\
\hline & Viselkedéses szándék & $\begin{array}{l}\text { A viselkedés folytatásának észlelt } \\
\text { valószínüsége }\end{array}$ & $\begin{array}{l}\text { Bipoláris -3-tól +3-ig terjedő } \\
\text { valószínütlen - valószínü skála }\end{array}$ \\
\hline \multirow{7}{*}{ 承 } & \multicolumn{3}{|l|}{ Tapasztalati (affektív) attitüd } \\
\hline & Direkt mérőszám & $\begin{array}{l}\text { A magatartás átfogó affektív } \\
\text { értékelése }\end{array}$ & $\begin{array}{l}\text { Szemantikus differenciálskálák, } \\
\text { pl. kellemes - kellemetlen, } \\
\text { élvezetes - nem élvezetes }\end{array}$ \\
\hline & $\begin{array}{l}\text { Indirekt mérőszám: } \\
\text { Magatartási hiedelem }\end{array}$ & $\begin{array}{l}\text { Arra vonatkozó hiedelem, hogy a } \\
\text { magatartás pozitív vagy negatív } \\
\text { érzelmekkel jár }\end{array}$ & $\begin{array}{l}\text { Bipoláris -3-tól +3-ig terjedő } \\
\text { valószínütlen - valószínű skála }\end{array}$ \\
\hline & \multicolumn{3}{|l|}{ Instrumentális attitüd } \\
\hline & Direkt mérőszám & A magatartás átfogó értékelése & $\begin{array}{l}\text { Szemantikus differenciálskálák, } \\
\text { pl. jó - rossz, bölcs dolog - } \\
\text { butaság }\end{array}$ \\
\hline & $\begin{array}{l}\text { Indirekt mérőszám: } \\
\text { Magatartási hiedelem }\end{array}$ & $\begin{array}{l}\text { Arra vonatkozó hiedelem, hogy a } \\
\text { magatartás bizonyos jellemzőkkel } \\
\text { vagy kimenetekkel jár }\end{array}$ & $\begin{array}{l}\text { Bipoláris -3-tól +3-ig terjedő } \\
\text { valószínütlen - valószínű skála }\end{array}$ \\
\hline & Értékelés & $\begin{array}{l}\text { A magatartás valamely kimenetéhez } \\
\text { vagy jellemzőjéhez kapcsolt érték }\end{array}$ & $\begin{array}{l}\text { Bipoláris -3-tól +3-ig terjedő } \\
\text { jó - rossz skála }\end{array}$ \\
\hline \multirow{7}{*}{ 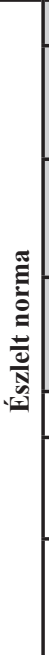 } & \multicolumn{3}{|l|}{ Szubjektiv (elöiró) norma } \\
\hline & Direkt mérőszám & $\begin{array}{l}\text { Arra vonatkozó hiedelem, hogy a } \\
\text { legtöbb ember jóváhagyja, vagy nem } \\
\text { hagyja jóvá a magatartást }\end{array}$ & $\begin{array}{l}\text { Bipoláris -3-tól +3-ig terjedő } \\
\text { egyetért - nem ért egyet skála }\end{array}$ \\
\hline & $\begin{array}{l}\text { Indirekt mérőszám: } \\
\text { Normatív hiedelem }\end{array}$ & $\begin{array}{l}\text { Arra vonatkozó hiedelem, hogy az } \\
\text { egyes referenciaszemélyek jóváhagy- } \\
\text { ják-e vagy sem a magatartást }\end{array}$ & $\begin{array}{l}\text { Bipoláris -3-tól +3-ig terjedő } \\
\text { egyetért - nem ért egyet skála }\end{array}$ \\
\hline & $\begin{array}{l}\text { Megfelelés } \\
\text { motivációja }\end{array}$ & $\begin{array}{l}\text { Annak motivációja, hogy azt tegye, } \\
\text { amit az egyes referenciaszemélyek } \\
\text { elvárnak }\end{array}$ & $\begin{array}{l}\text { 1-től 7-ig terjedő valószínütlen } \\
\text { - valószínủ skála }\end{array}$ \\
\hline & \multicolumn{3}{|l|}{ Leiró norma } \\
\hline & Direkt mérőszám & $\begin{array}{l}\text { Arra vonatkozó hiedelem, hogy a leg- } \\
\text { több ember folytatja-e a magatartást }\end{array}$ & $\begin{array}{l}\text { Bipoláris -3-tól +3-ig terjedő } \\
\text { egyetért - nem ért egyet skála }\end{array}$ \\
\hline & $\begin{array}{l}\text { Indirekt mérőszám: } \\
\text { Normatív hiedelem }\end{array}$ & $\begin{array}{l}\text { Arra vonatkozó hiedelem, hogy az } \\
\text { egyes referenciaszemélyek } \\
\text { folytatják-e a magatartást }\end{array}$ & $\begin{array}{l}\text { Bipoláris -3-tól +3-ig terjedő } \\
\text { egyetért - nem ért egyet skála }\end{array}$ \\
\hline
\end{tabular}




\section{3. táblázat (folytatás) \\ Table 3 (continue)}

\begin{tabular}{|c|c|c|c|}
\hline & \multirow{2}{*}{\begin{tabular}{|l|} 
Konstrukció \\
Észlelt magatartásirányit
\end{tabular}} & Definíció & \multirow[t]{2}{*}{ Mérés } \\
\hline & & & \\
\hline \multirow{6}{*}{ 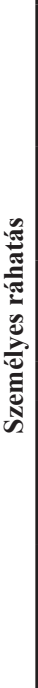 } & Direkt mérőszám & $\begin{array}{l}\text { A magatartás felett észlelt kontroll } \\
\text { átfogó méröszáma }\end{array}$ & $\begin{array}{l}\text { Szemantikus differenciálskálák, } \\
\text { pl. az irányításom alatt van } \\
\text { - nincs az irányításom alatt, } \\
\text { könnyü - nehéz } \\
\end{array}$ \\
\hline & $\begin{array}{l}\text { Indirekt méröszám: } \\
\text { Kontrollhiedelem }\end{array}$ & $\begin{array}{l}\text { Az egyes elősegitő és korlátozó } \\
\text { feltételek megjelenésének észlelt } \\
\text { valószínűsége }\end{array}$ & $\begin{array}{l}\text {-3-tól +3-ig vagy 1-től 7-ig } \\
\text { terjedő valószínütlen - való- } \\
\text { színủ skála }\end{array}$ \\
\hline & Észlelt hatás & $\begin{array}{l}\text { Az egyes feltételek magatartást meg- } \\
\text { könnyítő vagy megnehezítő hatása }\end{array}$ & $\begin{array}{l}\text { Bipoláris -3-tól +3-ig terjedö } \\
\text { nehéz - könnyű skála }\end{array}$ \\
\hline & Énhatékonyság & & \\
\hline & Direkt mérőszám & $\begin{array}{l}\text { A magatartást lehetővé tévő } \\
\text { képességek átfogó mérőszáma }\end{array}$ & $\begin{array}{l}\text {-3-tól +3-ig vagy 1-től 7-ig ter- } \\
\text { jedő „biztos, hogy nem vagyok } \\
\text { képes - biztos, hogy képes } \\
\text { vagyok” átfogó skála }\end{array}$ \\
\hline & $\begin{array}{l}\text { Indirekt mérőszám: } \\
\text { Énhatékonysági } \\
\text { hiedelem }\end{array}$ & $\begin{array}{l}\text { Az észlelt képesség az egyes } \\
\text { elősegítő vagy korlátozó tényezők } \\
\text { leküzdésére }\end{array}$ & $\begin{array}{l}\text {-3-tól +3-ig vagy 1-tő1 7-ig ter- } \\
\text { jedő ,biztos, hogy nem vagyok } \\
\text { képes - biztos, hogy képes } \\
\text { vagyok” skála }\end{array}$ \\
\hline
\end{tabular}

Megjegyzés: A TRA/TPB konstrukciók szürke háttérrel jelölve.

Forrás: Montaño \& Kasprzyk (2008)

Ebben a modellben a magatartási hiedelmeket arra vonatkozóan, hogy a magatartás bizonyos kimenetekkel jár kétpólusú „,valószínútlen - valószínü” vagy „,nem értek egyet - egyetértek” végpontú skálákon mérik, az egyes kimenetek értékelését pedig ,jó - rossz" végpontú skálán. Például a dohányzás abbahagyásának egy lehetséges kimenete lehet a hízás. A magatartási hiedelem ezzel a kimenettel kapcsolatban úgy mérhető, hogy a válaszadónak azt kell megbecsülnie, hogy mi a valószínüsége annak, hogy ,ha abbahagyom a dohányzást, hízni fogok". A magatartás kimenetének értékelése során pedig a válaszadónak azt kell eldöntenie, hogy az, hogy „hízni fogok” mennyire jó vagy rossz. Mindkét esetben -3-tól +3-ig terjedő skálákon történik az értékelés, majd az attitüd indirekt mérőszáma a két értékelés kimenetenkénti szorzatainak összegeként (és nem súlyozott átlagként, mint a modellek többségénél) áll elő. Például az egyén hihet abban, hogy a dohányzás abbahagyása nagyon valószínútlen, hogy hízást okoz (hiedelem: -3) és értékelheti a hízást mint nagyon rossz kimenetet (értékelés: -3). Ez (vagyis az a hiedelem, hogy a magatartás nem vezet egy negatívan értékelt kimenethez) ugyanúgy +9-es szorzathoz (az attitüd indirekt mérőszáma), azaz a dohányzás abbahagyása iránti nagyon pozitív attitüdhöz vezet, mint az a hiedelem, hogy a dohányzás abbahagyása nagyon valószínü, hogy hízást okoz (+3), és a hízást a személy nagyon pozitív fejleményként értékeli $(+3)$. Ezzel szemben ha a személy úgy hiszi, hogy a dohányzás nagyon valószínütlen, hogy hízáshoz vezet (-3), viszont a hízás kívánatos a számára (+3), az ugyanúgy negatív attitüdhöz vezet a dohányzás abbahagyásával szemben (-9), mint ha úgy vélné, hogy nagyon valószínủ, hogy hízást okoz $(+3)$, viszont a hízás nemkívánatos számára (-3) (Montaño \& Kasprzyk 2008).

Az attitüd indirekt méréséhez hasonlóan a normatív hiedelmeket azzal kapcsolatban, hogy az egyes referenciaszemélyek úgy gondolják, hogy az egyénnek egy adott módon kell viselkednie, egy -3-tól +3-ig terjedő skálán mérik, míg az egyén motivációját, hogy megfeleljen az egyes referenciaszemélyeknek, egy 1-től 7-ig tartó skálán. Például ha egy referenciaszemély az egyén legjobb barátja, akkor a vele kapcsolatos normatív hiedelem úgy mérhetö, hogy az egyénnek értékelnie kell azt, hogy mennyire hiszi úgy, hogy a barátja szerint abba kellene hagynia a dohányzást. A megfelelés motivációját pedig úgy mérik, hogy a válaszadónak értékelnie kell, hogy mennyire ért egyet azzal a kijelentéssel, 
hogy „Általában azt akarom tenni, amit a legjobb barátom szerint kell tennem.” A szubjektív norma indirekt mérése pedig úgy történik, hogy az egyes referenciaszemélyekhez kapcsolódó normatív hiedelmek és a megfelelés motivációjának szorzatait összegezzük (Montaño \& Kasprzyk 2008).

A kontrollhiedelmeket az egyes körülmények felmerülési valószínúségének -3 -tól +3 -ig terjedő skáláján mérik, az észlelt hatásukat pedig -3-tól +3-ig terjedö, „,könnyü - nehéz” végpontú skálán (Ajzen 1991). Például a válaszadó gondolhatja azt, hogy az, hogy az éttermek korlátozzák a dohányzást, befolyásolja az észlelt magatartás irányítását. Ekkor az erre vonatkozó kontrollhiedelmet úgy lehet mérni, hogy az egyénnel értékeltetjük, hogy mennyire gondolja valószínủnek, hogy találkozik ilyen korlátozással, az észlelt hatást pedig úgy, hogy azt értékeltetjük vele, hogy ez a korlátozás mennyire könnyíti vagy nehezíti meg a dohányzásról való leszokást. Az észlelt magatartásirányítás indirekt mérése az előző indirekt mérésekhez hasonlóan az egyes tényezőkre vonatkozó kontrollhiedelmek és az észlelt hatásuk szorzatainak összegeként áll elö (Ajzen \& Driver 1991).

$\mathrm{Az}$ egyes modellkonstrukciók fent ismertetett indirekt mérése mellett fontos azokat közvetlenül is mérni. Ennek oka, hogy a direkt mérőszámok általában erősebben összefüggnek a viselkedéses szándékkal és a viselkedéssel. Az adott magatartással szembeni attitüd direkt mérése szemantikus differenciálskálák (például ,jó - rossz”, „,kellemes - kellemetlen" végpontokkal) összegzésével történhet. A szubjektív norma direkt mérésére a személynek értékelnie kell egy „,valószínütlen - valószínü” vagy „egyetért - nem ért egyet” végpontú skálán azt az állítást, hogy „A legtöbb, számomra fontos személy szerint folytatnom kellene" az adott magatartást. Az észlelt magatartásirányítás direkt mérése szemantikus differenciálskálákon történhet „,az irányításom alatt áll - nem áll az irányításom alatt" vagy „könnyü - nehéz” végpontokkal (Montaño \& Kasprzyk 2008).

Előfordul, hogy bár a kutatók szándékuk szerint a mögöttes, indirekt konstrukciókkal kívánják a direkt befolyásoló tényezőket közelíteni, kide- rül, hogy nem sikerült pontosan ugyanazt mérni a kettővel, ezért külön direkt tényezőként kerül a modellbe egy indirektnek szánt konstrukció. Ez történt például Kasprzyk et al. (1998), Kenski et al. (2001), von Haeften et al. (2001) és von Haeften és Kenski (2001) kutatásában, ahol a súlyozott kontrollhiedelmek ${ }^{3}$ nem mutattak korrelációt az észlelt magatartásirányítással - ellentétben Ajzen (1991) konceptualizációjával -, erősen korreláltak viszont a viselkedéses szándékkal. Olyan esetre is akad példa, hogy az indirekt tényezők esetén az értékaspektus (a viselkedés kimenetének értékelése, a referenciaszemélyeknek való megfelelés motivációja) nem olyan mértékben hat a szándékra, mint maguk a hiedelmek (magatartási hiedelmek, normatív hiedelmek), így csak az utóbbiak maradnak a modellben, súlyozatlanul. Az is elöfordulhat, hogy valamely direkt vagy indirekt konstrukció mentén a válaszadók nagyon homogén válaszokat adnak, mint például Kasprzyk és Montaño (2007) tanulmányában az észlelt kontrollra vonatkozó kérdések esetén. Ilyenkor érdemes az adott tényezőt kihagyni a vizsgálatból.

Ha a szerkezeti érvényesség (construct validity), azaz a modellkonstrukciók belső konzisztenciája megfelelőnek bizonyul ${ }^{4}$, a konstrukciók közti összefüggések feltárására többszörös hierarchikus és/vagy stepwise regresszióelemzést, illetve strukturális egyenlet modellezést (SEM) végeznek. A tanulmányok egy része ezt három lépésben teszi meg (Kasprzyk \& Montaño 2007), először a TRA-t alkotó attitűd és szubjektív norma direkt változói kerülnek be a modellbe, majd ehhez képest a TPBben további elemként szereplő énhatékonyság. Harmadik lépésben stepwise regresszióanalízis során az indirekt tényezők kerülnek be a modellbe, hogy meghatározzák, hogy ezen indirekt konstrukciók növelik-e a TPB magyarázóerejét a viselkedéses szándékra vonatkozóan. Végül annak feltárására, hogy a mögöttes hiedelmek (magatartási, normatív, énhatékonyság) mely változóinak van a legnagyobb hatása a viselkedéses szándékra, a szerzőpáros korrelációelemzést, majd a szándékot előrejelző hiedelmekkel és a szignifikáns direkt konstrukciókkal stepwise regresszióanalízist

\footnotetext{
3 A tényező Kasprzyk et al. (1998) tanulmányában elösegítő/hátráltató tényezők (facilitators/contraints) néven szerepel.

4 Ha a Cronbach alfával vagy korrelációval mért belső konzisztencia alacsony (vagyis az elméleti konstrukciót alkotó változók nem ugyanazt mérik), akkor a változókat nem lehet egy azon konstrukció részeként tekinteni, hanem külön befolyásoló tényezőkként kell a modellben vizsgálni, ahogy ez Kasprzyk et al. (1998) tanulmányában a kritikus események változóinál történt. Rhodes et al. (2007) konfirmatorikus faktorelemzéssel (CFA) tárta fel, hogy az indirekt mérések megfelelnek-e a modell által elöirányzott konstrukcióknak, Braun (2012) pedig feltáró főkomponens-elemzést alkalmazott (PCA).
} 
végzett. Kasprzyk et al. (1998), von Haeften et al. (2001) valamint von Haeften és Kenski (2001) ezzel szemben elöször az összes direkt befolyásoló tényezőt léptette be a regressziós modellbe, majd ezt követően a köztük lévő szignifikáns interakciókat, majd harmadik lépésként a kritikus eseményeket. Von Haeften et al. (2001) és von Haeften és Kenski (2001) második lépésként - hasonlóan Kasprzyk és Montaño (2007) kutatásához - a mögöttes hiedelmek és a szándék között korrelációelemzést, majd a szándékot előrejelző hiedelmekkel és a szignifikáns direkt konstrukciókkal stepwise regresszióanalízist végzett. Végül annak meghatározására, hogy a szignifikáns hatással bíró indirekt befolyásoló tényezők esetén a hiedelmek vagy azok súlya játszik-e szerepet a szignifikáns hatásban, a hiedelmek és a szándék, valamint a súlyok és a szándék között korrelációszámítást végzett.

\section{A MAGATARTÁS BEFOLYÁSO- LÁSÁRA TETT AJÁNLÁSOK AZ INTEGRÁLT VISELKEDÉSES MODELL ALAPJÁN RECOMMENDATIONS FOR INFLUENCING BEHAVIOUR BASED ON THE INTEGRATED BEHAVIORAL MODEL}

Általánosságban kijelenthető, hogy az IBM konstrukciói jól előrejelzik a viselkedéses szándékot és - ahol vizsgálták - magát a viselkedést is. A modell ezért jól alkalmazható az egészségmagatartás különböző aspektusaival kapcsolatos konkrét beavatkozásokra vonatkozó javaslatok generálására.

A viselkedésváltozást célzó beavatkozások tárgya az IBM alapján attól függ, hogy a célcsoport rendelkezik-e már erős szándékkal a viselkedés irányában, illetve követi-e már az adott magatartást. Más és más beavatkozásra lesz ugyanis szükség, ha egy személy szándékozik egy adott módon viselkedni és ennek megfelelően cselekszik is, vagy ha ugyan szándékában áll az adott magatartást követni, de valami miatt nem képes a szándékát megvalósítani, illetve ha nincs is szándékában a magatartást folytatni (Fishbein 2000, Fishbein et al. 2002, Fishbein \& Cappella 2006). E két dimenzió a beavatkozások négy irányát veti fel (1. ábra).

1. ábra: Szándék-viselkedés mátrix

Figure 1. Intention-behaviour matrix

\section{Az ajánlott viselkedés folytatása}

\begin{tabular}{|l|l|l|}
\multicolumn{2}{c}{} & \multicolumn{1}{c}{ Nem } \\
\cline { 2 - 3 } $\begin{array}{l}\text { Az ajánlott viselkedésre } \\
\text { vonatkozó szándék }\end{array}$ & $\begin{array}{l}\text { A mögöttes befolyásoló tényezök (magatartási, normatív és } \\
\text { énhatékonysági hiedelmek) megváltoztatása }\end{array}$ \\
\cline { 2 - 3 } & $\begin{array}{l}\text { Képességek fejlesztése, kör- } \\
\text { nyezeti korlátok csökkentése, a } \\
\text { célcsoport segítése a leküzdé- } \\
\text { sükben }\end{array}$ & $\begin{array}{l}\text { Nem szükséges beavatkozás / } \\
\text { a pozitív szándék fenntartása }\end{array}$ \\
\cline { 2 - 3 } &
\end{tabular}

Forrás: Fishbein \& Yzer (2003) alapján saját átalakitás 
Először azt kell eldönteni, hogy mely cellába tartozókat szeretnénk a beavatkozással megcélozni, ebben a cellagyakoriságok segítenek (Fishbein \& Cappella 2006). Amennyiben a célcsoport még nem rendelkezik erős szándékkal a magatartás követésére, és emiatt nem mutatja a kívánt viselkedést, az IBM szerint a szándékot befolyásoló három direkt, illetve az azok mögött meghúzódó indirekt tényezőket kell különböző beavatkozásokkal (például kommunikációs stratégiákkal) célozni (Fishbein et al. 2002, Fishbein \& Cappella 2006, Fishbein \& Yzer 2003). Ha a célszemélyeknek megvan a szándéka az adott viselkedés követésére, de mégsem cselekszenek annak megfelelően, akkor nem kommunikációval lehet a magatartás irányába elmozdítani őket, hanem a beavatkozásnak érdemes vagy a képességek fejlesztését, vagy a környezeti korlátok elhárítását (illetve a célcsoport segítését, hogy leküzdje azokat) céloznia (Fishbein 2000, Fishbein et al. 2002, Fishbein \& Cappella 2006, Fishbein \& Yzer 2003). Ha a célcsoport tagjai erös szándékkal rendelkeznek egy adott magatartás irányában és ennek megfelelően viselkednek, akkor nincs szükség beavatkozásra, vagy a pozitív szándék fenntartását kell célozni (Fishbein \& Cappella 2006, Fishbein \& Yzer 2003). A legtöbb magatartás esetén a mátrix aszimmetrikus, azaz ha valakinek nem áll szándékában egy magatartást követni, nagyon valószínútlen, hogy mégis megteszi (Fishbein \& Cappella 2006). De ha ez mégis bekövetkezik, azaz ha a célcsoport már mutatja a kívánt magatartást, de nincs mögötte egy erős szándék, a magatartás valószínűleg nem lesz fenntartható. Ebben az esetben ezért ugyanolyan beavatkozásra van szükség a szándék kialakítására, mint amikor nem követik a magatartást és ez nincs is szándékukban.

Amennyiben a viselkedésváltozás akadálya a viselkedéses szándék hiánya, úgy elöször ezt kell megteremteni. Ez az a pont, ahol az IBM a segítségünkre lehet, ugyanis a modellkonstrukcióinak relatív súlya a regressziós/SEM modellekben (illetve a korrelációjuk a viselkedéses szándékkal) jelzi azt, hogy melyik tényező(k)re kell fókuszálni a viselkedésváltozást célzó erőfeszítéseket (Fishbein \& Cappella 2006, Montaño \& Kasprzyk 2008). A konkrét javaslatok nem a direkt, hanem az indirekt befolyásoló tényezőkre, azaz a hiedelmekre építhetnek (Fishbein \& Cappella 2006, von Haeften et al. 2001), ugyanis míg a direkt tényezők megmutatják, hogy mekkora a valószínüsége, hogy az egyén követni fogja a magatartást, addig az indirekt tényezők adnak magyarázatot arra, hogy miért vagy miért nem követi az adott magatartást (Braun 2012). Másképpen fogalmazva, ugyan tudhatjuk, hogy egy adott viselkedés iránti szándékot elsősorban mely direkt tényező befolyásolja, ez nem ad útmutatást arra vonatkozóan, hogy hogyan lehetne ezeket befolyásolni (Fishbein \& Cappella 2006).

Az indirekt tényezők esetén lényeges lehet megvizsgálni, hogy maguk az indirekt tényezők (viselkedési hiedelmek, normatív hiedelmek, kontrollhiedelmek) vagy a súlyok (a viselkedés kimenetének értékelése, a megfelelés motivációja, az észlelt hatás) - esetleg mindkettő - bírnak-e szignifikáns hatással, illetve a tényezökön belül mely konkrét elemek befolyásolnak (Kenski et al. 2001), és a javaslatokat a legerősebb befolyással bíró tényezőkre építeni (Rhodes et al. 2007).

Néhány kutatás kimutatta, hogy a modell konstrukciói néha nem (csak) önmagukban hatnak a viselkedésre vagy a viselkedéses szándékra, hanem az interakciójuk is (például az attitüd és a kontrollhiedelmek Kasprzyk et al. 1998 tanulmányában). Ilyenkor a beavatkozásoknak egyszerre mindegyik faktort meg kell célozniuk, ugyanis csupán az egyik tényező megváltoztatása nem várt, nemkívánatos hatással lehet a többire.

Csupán néhány hiedelem megcélzása hatástalan lehet akkor, ha a viselkedéses szándékra ható hiedelmek teljes köréhez képest csak kis részt képviselnek (Montaño \& Kasprzyk 2008). Nem szükséges - és sokszor nem is megvalósítható ugyanakkor egy-egy direkt vagy indirekt tényező összes elemét célozni a viselkedésváltozásra irányuló beavatkozással, hanem ki kell választani azokat, amelyek a legnagyobb hatással bírnak az adott tényezőre (Kasprzyk \& Montaño 2007, Montaño \& Kasprzyk 2008). Ehhez Fishbein és Yzer (2003) valamint Fishbein és Cappella (2006) azt a megfontolást javasolja Hornik és Woolf (1999) tanulmányára építve, hogy a hiedelemnek szignifikáns kapcsolatban kell állnia a viselkedéssel (magas szignifikáns korreláció), emellett ahhoz, hogy megérje beavatkozni, elegendő ember kell, akik még nem rendelkeznek az adott hiedelemmel. E hiedelmek az ún. diszkrimináló hiedelmek (Fishbein \& Yzer 2003), hiszen elválasztják egymástól a hiedelemmel rendelkezőket és nem rendelkezőket. A diszkrimináló hiedelmek megtalálásához érdemes összehasonlítani az adott hiedelmekkel (a megfogalmazástól függően) egyetértő/egyet nem értő válaszadók arányát a vizsgált magatartást folytatni szándékozó és nem szándékozó válaszadók körében. A magatartást folytatni nem szándékozók esetén a relatíve alacsony arány az azt folytatni szándékozókhoz viszonyítva jelentős potenciált jelez a beavatkozásra egy adott hiedelem esetén, ugyanis itt még nagy tere van a nem szándékozók körében a hiedelemmel való egyetértés/egyet nem értés mértékének növelésének (Montaño \& Kasprzyk 2008). 
$\mathrm{Az}$ is elöfordulhat, hogy egy szignifikáns elem nehezen (vagy egyáltalán nem) változtatható, bár ennek megitélése erősen szubjektív; mindenesetre az elmondható, hogy azokat a hiedelmeket, melyek közvetlen tapasztalaton alapulnak, nehezebb megváltoztatni, mint azokat, amelyek következtetésen alapulnak vagy valamilyen külső információforrásból származnak (Fishbein et al. 2001, 2002). Ilyen esetben a nehezen változtatható változót más, könnyebben változtathatóval érdemes helyettesíteni (von Haeften \& Kenski 2001). Például arról valószínüleg nehéz meggyőzni az embereket, hogy fesztelenebbül fogják magukat érezni, ha használnak óvszert (habár ez a hiedelem szignifikáns befolyással bír a viselkedéses szándékra), arról talán könnyebben meggyőzhetők, hogy az óvszerhasználat a partnerüket tenné fesztelenebbé, ezért érdemes erre fókuszálni, amennyiben ez is szignifikáns hatással van a szándékra. Viszont amennyiben a hiedelmek belső konzisztenciája alacsony, úgy a helyettesítéssel óvatosan kell bánni (von Haeften et al. 2001).

A viselkedésváltozást célzó beavatkozások tervezésénél azt is érdemes figyelembe venni, hogy bár az IBM elméleti konstrukciói érvényesnek bizonyultak számos kultúrában (Fishbein 2000), az azonban, hogy mely modellkonstrukciónak van (nagyobb) hatása a viselkedéses szándékra vagy a viselkedésre, illetve az, hogy a mögöttes tényezök milyen változókból (hiedelmekből) állnak össze még egy adott magatartásforma esetén is jelentős eltéréseket mutat, sokszor kockázati célcsoporttól, nemtől, etnikumtól és természetesen kultúrától függ. Például az óvszerhasználat állandó partnerrel droghasználó nők esetén elsősorban normatív befolyás alatt áll, míg drogot nem használó nők esetén az attitüd, a norma és az észlelt kontroll is befolyásol (von Haeften \& Kenski 2001). Hasonlóan, Rhodes et al. (2007) kutatása megmutatta, hogy - bár az állandó partnerrel való óvszerhasználati szándék elsődleges meghatározója az attitüd mindkét nemnél - az énhatékonyság relatíve sokkal fontosabb volt a nőknél, mint a férfiaknál.

Az eltérések még nagyobb valószínüséggel jelennek meg akkor, ha eltérő magatartásformákat vizsgálunk. Smith-McLallen és Fishbein (2008) kutatása például feltárta, hogy 40 év fölötti felnőttek esetén a kolonoszkópia igénybe vételének szándékát szinte kizárólag normák határozzák meg, míg a testmozgás gyakorlásának szándékát elsődlegesen az észlelt magatartásirányítás, másodsorban pedig az attitűd befolyásolja. Az IBM tehát populáció- és magatartásspecifikus (Fishbein \& Cappella 2006), éppen ezért a modell alapján kidolgozott beavatkozások nem lehetnek univerzálisak (Fishbein et al. 2002), ehelyett a különböző magatartásformák, kultúrák és célcsoportok szerint ,,személyre szabottak" kell, hogy legyenek (Fishbein 2000, Fishbein \& Cappella 2006, Fishbein \& Yzer 2003).

Végül nem szabad szem elöl téveszteni azt sem, hogy a TRA, a TPB és az IBM a viselkedéses szándékot és a viselkedést magyarázó elméletek, melyek a beavatkozás irányát segíthetnek azonosítani, de nem kommunikációs elméletek, így semmit nem mondanak arról, hogy milyen eszközökkel kellene a modellkonstrukciókat megváltoztatni, azaz, hogy konkrétan milyen üzenetet és milyen csatornákon kellene eljuttatni a célcsoportokhoz az optimális eredmény elérése érdekében.

\section{ÖSSZEFOGLALÁS SUMMARY}

A hazai és nemzetközi szakirodalomban számos elmélet található, melyek a különböző magatartásformákat - köztük az egészségmagatartás különböző formáit - igyekeznek megmagyarázni. E modellek egy népszerü körét alkotják a társaskognitív magatartási modellek, melyek segítséget nyújtanak a viselkedés mögött meghúzódó hiedelmek azonosításához, amelyek aztán a viselkedésváltozást célzó beavatkozások alapjául szolgálhatnak. Ezen elméletek - a számos különbég ellenére - összeegyeztethetők, integrálásukkal létrejött a szakirodalomban némileg eltérő neveken és formában megtalálható integrált viselkedéses modell.

A modell sikeresnek bizonyult számos egészségmagatartás-forma magyarázatában, elörejelzésében és a viselkedésváltozást célzó programok megalapozásában is, mégsem terjedt el széles körben a használata, különösen a hazai szakirodalomban. A szerzők tudomása szerint csupán egy hazai empirikus kutatás alkalmazta, mégpedig az egészségmagatartás területén, holott az egészségmagatartás mellett alkalmas lenne akár egyéb magatartásformák vizsgálatára is. Kétrészes tanulmányunk ezért azzal a céllal íródott, hogy elméleti áttekintést adjon az integrált viselkedéses modell felépítéséről és használatának módjáról, ezzel segítve a jövőbeli alkalmazását a hazai empirikus kutatásokban az egészségmagatartás (és esetleg más magatartásformák) területén.

A szakirodalomban fellelhető integrált viselkedéses modellek - bár némileg eltérnek egymástól - közös vonása, hogy feltételezik, hogy a viselkedés legfőbb befolyásolója a viselkedéses szándék, amelyet közvetlenül az attitüd, a szubjektív norma és az észlelt magatartásirányítás vagy énhatékonyság határoz meg. A modell azt is feltételezi, hogy a 
direkt tényezők mögött meghúzódnak azok a hiedelmek, melyek indirekt módon hatnak a viselkedéses szándékra. Így az attitűd mögött a magatartási hiedelmek, a szubjektív normák mögött a normatív hiedelmek, az észlelt magatartásirányítás vagy énhatékonyság mögött pedig a kontrollhiedelmek vagy énhatékonysági hiedelmek állnak.

Amennyiben az egyén pozitív szándékkal rendelkezik a magatartás irányában, de mégsem mutatja azt a magatartást, a modell szerint egyéb, a viselkedést közvetlenül befolyásoló tényezőkkel kell számolnunk. A legszélesebb körben (és az egyetlen magyar kutatásban) használt modell (Montaño \& Kasprzyk 2008) szerint négy ilyen tényezőt kell figyelembe venni. Az egyén akkor fog egy adott magatartást követni, ha a szándék mellett megfelelő ismeretekkel és képességekkel rendelkezik, nincsenek áthidalhatatlan környezeti akadályok, a magatartás kiemelkedően fontos a számára, illetve ha a magatartás már szokássá vált.

A megfelelően, kvalitatív kutatással megalapozott, így az adott populációhoz és magatartáshoz igazított kérdőív megbízhatóan képes a modellkonstrukciókat mérni. A köztük lévő kapcsolatok feltárására korrelációszámítást, többszörös regressziószámítást, illetve strukturális egyenlet modellezést használhatunk. Ezek révén lehetséges azonosítani azokat a hiedelmeket, melyek leginkább magyarázzák a viselkedéses szándékot, így - amennyiben a magatartás akadálya a szándék hiánya - ezekre érdemes első körben fókuszálni a magatartásváltozást célzó beavatkozásokat.

Nem szabad ugyanakkor elfelejteni, hogy az IBM csak a beavatkozások lehetséges tárgyát képes azonosítani, arról viszont nem mond semmit, hogy milyen eszközökkel kellene az adott hiedelmeket megváltoztatni. Ezen a ponton a kommunikációs elméleteket kell segítségül hívni.

\section{HIVATKOZÁSOK REFERENCES}

Ajzen, I. (1991), "The Theory of Planned Behaviour", Organizational Behavior and Human Decision Processes, 50(2), 179-211 DOI: 10.1016/0749-5978(91)90020-T

Ajzen, I. and Driver, B. (1991), "Prediction of Leisure Participation from Behavioral, Normative, and Control Beliefs: An Application of the Theory of Planned Behaviour", Leisure Sciences, 13(3), 185-204 DOI: 10.1080/01490409109513137

Braun, R. E. (2012), Using the Integrated Behavioral Model to Predict Binge Drinking Among College Students, Doctoral (PhD) Dissertation, The University of Toledo

Danter, E. H. (2005), The Intention-Behavior Gap: To What Degree Does Fishbein's Integrated Model of Behavioral Prediction Predict Whether Teachers Implement Material Learned in a Professional Development Workshop?, Doctoral (PhD) Dissertation, The Ohio State University

Fishbein, M. (2000), "The Role of Theory in HIV Prevention", AIDS Care, 12(3), 273-278 DOI: 10.1080/09540120050042918

Fishbein, M. (2007), “A Reasoned Action Approach: Some Issues, Questions, and Clarifications", in: Ajzen, I., Albarracin, D. and Hornik, R. (eds.): Prediction and Change of Health Behavior: Applying the Reasoned Action Approach, Lawrence Erlbaum, Mahwah, NJ. 281-296

Fishbein, M. and Yzer, M. C. (2003), "Using Theory to Design Effective Health Behavior Interventions", Communication Theory, 13(2), 164183 DOI: $10.1111 / j .1468-2885.2003 . t b 00287 . x$

Fishbein, M. and Cappella, J. N. (2006), "The Role of Theory in Developing Effective Health Communications", Journal of Communication, 56 S1, S1-S17 DOI: 10.1111/j.14602466.2006.00280.x

Fishbein, M., Triandis, H. C., Kanfer, F. H., Becker, M. H., Middlestadt, S. E. and Eichler, A. (2001), "Factors Influencing Behavior and Behavior Change", in: Baum, A., Revenson, T. R. and Singer, J. E. (eds.), Handbook of Health Psychology, Lawrence Erlbaum, Mahwah, NJ, 3-17

Fishbein, M., Cappella, J., Hornik, R., Sayeed, S., Yzer, M. and Ahern, R. K. (2002), "The Role of Theory in Developing Effective Antidrug Public Service Announcements", in: Crano, W. D. and Burgoon, M. (eds.), Mass Media and Drug Prevention: Classic and Contemporary Theories 
and Research, Lawrence Erlbaum, Mahwah, NJ, 89-117

Hornik, R. and Woolf, K. D. (1999), "Using Cross-Sectional Surveys to Plan Message Strategies", Social Marketing Quarterly, 5(1), 34-41 DOI: 10.1080/15245004.1999.9961044

Kasprzyk, D. and Montaño, D. E. (2007), “Application of an Integrated Behavioral Model to Understand HIV Prevention Behavior of HighRisk Men in Rural Zimbabwe", in: Ajzen, I., Albarracín, D. and Hornik, R. (eds.), Prediction and Change of Health Behavior: Applying the Reasoned Action Approach, Lawrence Erlbaum, Mahwah, NJ, 149-172

Kasprzyk, D., Montaño, D. E. and Fishbein, M. (1998), "Application of an Integrated Behavioral Model to Predict Condom Use: A Prospective Study among High HIV Risk Groups", Journal of Applied Social Psychology, 28(17), 1557-1583 DOI: $10.1111 /$ j.1559-1816.1998. tb01690.x

Kenski, K., Appleyard, J., von Haeften, I., Kasprzyk, D. and Fishbein, M. (2001), "Theoretical Determinants of Condom Use Intentions for Vaginal Sex with a Regular Partner among Male and Female Injecting Drug Users", Psychology, Health \& Medicine, 6(2), 179-190 DOI: 10.1080/13548500123751

Montaño, D. E. and Kasprzyk, D. (2008), “Theory of Reasoned Action, Theory of Planned Behav- ior, and the Integrated Behavioral Model", in: Glanz, K., Rimer, B. K. and Viswanath, K. (eds.), Health behavior and health education: Theory, research and practice, Jossey-Bass, San Francisco, 67-96

Rhodes, F., Stein, J. A., Fishbein, M., Goldstein, R. B. and Rotheram-Borus, M. J. (2007), "Using Theory to Understand How Interventions Work: Project RESPECT, Condom Use, and the Integrative Model", AIDS and Behavior, 11(3), 393407 DOI: 10.1007/s10461-007-9208-9

Smith-McLallen, A. and Fishbein, M. (2008), "Predictors of Intentions to Perform Six Cancer-Related Behaviours: Roles for Injunctive and Descriptive Norms", Psychology, Health \& Medicine, 13(4), 389-401 DOI: 10.1080/13548500701842933

Von Haeften, I., Fishbein, M., Kasprzyk, D. and Montaño, D. (2001). "Analyzing Data to Obtain Information to Design Targeted Interventions", Psychology, Health \& Medicine, 6(2), 151-164 DOI: $10.1080 / 13548500125076$

Von Haeften, I. and Kenski, K. (2001), "Multi-Partnered Heterosexual's Condom Use for Vaginal Sex With Their Main Partner as a Function of Attitude, Subjective Norm, Partner Norm, Perceived Behavioural Control, and Weighted Control Beliefs", Psychology, Health \& Medicine, 6(2), 165-178 DOI: $10.1080 / 13548500120035427$ 
Kiss Marietta $\mathrm{PhD}$, adjunktus kiss.marietta@econ.unideb.hu

Fehér András PhD, adjunktus feher.andras@econ.unideb.hu

Kontor Enikő PhD, adjunktus kontor.eniko@econ.unideb.hu

Debreceni Egyetem Gazdaságtudományi Kar

\section{Application of Integrated Behavioral Model to influence health behavior II.}

\section{THE AIMS OF THE PAPER}

Several theories can be found in domestic and international literature which try to explain different forms of health behavior. One direction of them are social-cognitive theories that have successfully predicted and explained several behaviors, including various health behaviors. Beside this, they have also served as the basis for numerous successful interventions aiming at behavioral changes. Although the Integrated Behavioral Model (IBM) - which was developed by integrating more social-cognitive behavioral models - proved to be similarly successful in explaining and predicting specific health behaviors, and in serving as a basis for programs aiming at behavioral changes, its application has not been widespread yet, especially in the Hungarian literature. The aim of our twopart series is to provide a literature review of the structure and the application methods of the model, assisting its future applications in domestic empirical research in the field of health (and maybe other types) behaviors.

\section{METHODOLOGY}

In our studies, Hungarian and international literature on the origin, structure, and practical applications of the IBM has been revealed and presented by secondary research.

\section{MOST IMPORTANT RESULTS}

The current study deals with the practical applications of IBM, while the first part described the theoretical bases and the structure of IBM. Since the model is almost totally missing from the Hungarian literature, the systematic review of related theoretical and empirical experiences can be seen as filling the gap.

\section{RECOMMENDATIONS}

The IBM can be applied successfully for health behaviors that the literature has tried to explain by other theories, based on the methodology and the previous examples found in the literature and presented in the current study.

Keywords: Integrated Behavioral Model, Theory of Reasoned Action, Theory of Planned Behavior, health behavior

Acknowledgement: This publication was supported by the EFOP-3.6.2-16-2017-00003 project. The project is co-financed by the European Union and the European Social Fund. 